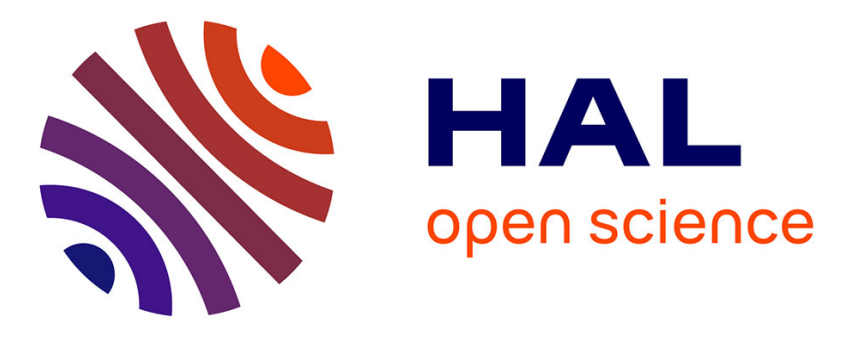

\title{
River Continuity Restoration and Diadromous Fishes: Much More than an Ecological Issue
}

\author{
Hilaire Drouineau, Caitriona Carter, M. Rambonilaza, G. Beaufaron, \\ Gabrielle Bouleau, Anne Gassiat, Patrick Lambert, S. Le Floch, S. Tétard, E. \\ de Oliveira
}

\section{To cite this version:}

Hilaire Drouineau, Caitriona Carter, M. Rambonilaza, G. Beaufaron, Gabrielle Bouleau, et al.. River Continuity Restoration and Diadromous Fishes: Much More than an Ecological Issue. Environmental Management, 2018, 61 (4), pp.671-686. 10.1007/s00267-017-0992-3 . hal-01817940

\author{
HAL Id: hal-01817940 \\ https://hal.science/hal-01817940
}

Submitted on 18 Jun 2018

HAL is a multi-disciplinary open access archive for the deposit and dissemination of scientific research documents, whether they are published or not. The documents may come from teaching and research institutions in France or abroad, or from public or private research centers.
L'archive ouverte pluridisciplinaire HAL, est destinée au dépôt et à la diffusion de documents scientifiques de niveau recherche, publiés ou non, émanant des établissements d'enseignement et de recherche français ou étrangers, des laboratoires publics ou privés. 


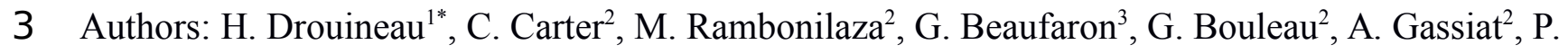

4 Lambert $^{1}$, S. le Floch ${ }^{2}$, S. Tétard ${ }^{4}$, E. de Oliveira ${ }^{4}$

5

61 - Irstea, UR EABX, 50 avenue de Verdun - 69336 Cestas Cedex, France

72 - Irstea, UR ETBX, 50 avenue de Verdun - 69336 Cestas Cedex, France

83 - EIFER, I Emmy-Noether-Str. 11 - 76131 Karlsruhe, Germany

94 - EDF-R\&D, LNHE 6 quai Watier, 78400 Chatou, France

$11 *$ corresponding author: hilaire.drouineau@irstea.fr

Abstract

14 Ecosystem fragmentation is a serious threat to biodiversity and one of the main challenges in

15 ecosystem restoration. River Continuity Restoration_(RCR) has often targeted diadromous fishes, a

16 group of species supporting strong cultural and economic values and especially sensitive to river

17 fragmentation. Yet it has frequently produced mixed results and diadromous fishes remain at very

18 low levels of abundance. Against this background, this paper presents the main challenges for

19 defining, evaluating and achieving effective RCR. We first identify challenges specific to

20 disciplines. In ecology, there is a need to develop quantitative and mechanistic models to support

21 decision making, accounting for both direct and indirect impacts of river obstacles and working at

22 the river catchment scale. In a context of dwindling abundances and reduced market value, cultural

23 services provided by diadromous fishes are becoming increasingly prominent. Methods for carrying

24 out economic quantification of non-market values of diadromous fishes become ever more urgent.

25 Given current challenges for rivers to meet all needs sustainably, conflicts arise over the legitimate 
26 use of water resources for human purposes. Concepts and methods from political science and

27 geography are needed to develop understandings on how the political work of public authorities and

28 stakeholders can influence the legitimacy of restoration projects. Finally, the most exciting

29 challenge is to combine disciplinary outcomes to achieve a multidisciplinary approach to RCR.

30 Accordingly, the co-construction of intermediary objects and diagrams of flows of knowledge

31 among disciplines can be first steps towards new frameworks supporting restoration design and 32 planning.

34 Keywords: diadromous fishes; river fragmentation; ecosystem goods and services; territory; policy; 35 multidisciplinary approach

\section{Context: an intensification of efforts towards RCR and diadromous fishes'}

protection

1.1 Ecosystem restoration and the specific case of River Continuity Restoration in the light of river fragmentation

42 increase in human welfare, ecosystem modifications due to anthropogenic activities were

43 threatening ecosystems' ability to sustainably provide important goods and services, especially for

44 future generations (Millennium Ecosystem Assessment 2005). This alarming situation applied to

45 both terrestrial and aquatic ecosystems. For example, rivers provide a multitude of goods and

46 services to society (Postel and Richter 2003; Wolanski et al. 2011; Elliott and Whitfield 2011) that

47 are potentially threatened due to many factors including: dam and dyke construction; pollution;

48 water extraction for human consumption or irrigation; drying out of lateral wetlands;

49 hydromorphological modifications; fishing; and land use in the floodplain (Elliott and Hemingway

50 2002; Postel and Richter 2003; Basset et al. 2013). In this article, using diadromous fishes and

51 River Continuity Restoration (RCR, i.e. restoring free movement of fishes and/or physical and 
Author-produced version of the article published in Environmental Management, 2018, 61(4), 671-686

The original publication is available at https://link.springer.com/

doi : 10.1007/s00267-017-0992-3

52 ecological components continuum) in France as an example, we will illustrate the need for an

53 interdisciplinary approach to conceptualize, achieve and evaluate effective ecosystem restoration for

54 diadromous fishes and identify key challenges raised by such an approach.

55 Indeed, ecological fragmentation disrupting ecological connectivity has been defined as one of the

56 major challenges in ecosystem restoration and conservation (Tischendorf and Fahrig 2000a, b;

57 Kondolf et al. 2006; Crook et al. 2009; Humphries and Winemiller 2009; Sutherland et al. 2013).

58 The notion of "ecological connectivity/continuity" or more generally "landscape connectivity"

59 comes from landscape ecology (Forman and Godron 1986). Ecological connectivity refers to the

60 possibility of genes, individuals, energy or matter to move from an ecological patch (defined as a

61 homogeneous unit of environment) to another because of the landscape structure (Ward and

62 Stanford 1995; Ward et al. 1999). Ecosystem fragmentation can arise from natural or anthropogenic

63 obstacles that impair animal movements. Dams or mill-weirs are among the most typical examples

64 of obstacles in the case of river connectivity. Such obstacles can either be transversal (weirs,

65 dams...), i.e. affecting movements upstream / downstream, or lateral (dykes), i.e. impacting

66 movements between a river and its floodplain.

67 In aquatic ecosystems, river fragmentation has significant impacts on fish assemblages'

68 composition, abundance and spatial distribution (Matthews and Robison 1998; Poulet 2007; Araújo

69 et al. 2009; Nislow et al. 2011; Perkin and Gido 2012; Gardner et al. 2013), and on the resilience of

70 populations because of genetic isolation (Jager et al. 1999, 2001; Fagan 2002; Horreo et al. 2011;

71 Webb and Padgham 2013). However, river fragmentation has other kinds of impacts on ecosystem

72 functioning such as habitat alteration or modification, variation of water table recharge, reduced

73 denitrification, modification of flood regimes or changes in the interdependency between the river

74 and its floodplain (Nilsson and Berggren 2000; Gergel et al. 2005). RCR aims at enhancing river

75 ecological functioning by favouring a longitudinal biotic and physical continuum (Vannote et al.

76 1980), as well as a lateral continuity between rivers and their floodplains (Amoros and Roux 1988)

77 and also a vertical continuity between the water column and river sediment. 
78 In view of this, initiatives to restore river continuity have flourished at international, national and

79 regional scales. In Europe for example, the Water Framework Directive (WFD - 2000/60/CE)

80 established new requirements in order to achieve good ecological status of water bodies in each

81 European Union (EU) Member State and specifically mentioned river continuity as a key

82 component of good ecological status. In France, the WFD resulted, inter alia, in the implementation

83 of a water and aquatic environments' law (Loi n 2006-1772 30 December, 2006 sur l'eau et les

84 milieux aquatiques: LEMA) which implements a new river classification system to prioritize rivers

85 in which continuity must be restored or protected. Recently, the "Blue and Green Infrastructure"

86 policies implemented in light of both the French environmental programme 2008 (Grenelle de

87 l'Environnement), and the EU's “Green Infrastructure Strategy” (COM(2013) 249 final), detail

88 specific projects on terrestrial and aquatic continuity preservation and restoration, based on a

89 network of classified patches of biodiversity interconnected along ecological corridors (Forman and

90 Godron 1986).

91

\subsection{Diadromous fishes: high value species impacted by river fragmentation}

93 Diadromous fishes refer to approximatively 250 species that share their life cycles between

94 freshwater and marine habitats (Myers 1949; McDowall 1997). Many of them are iconic food and

95 sport fishes, and have been intensively studied (Bloom and Lovejoy 2014). As an illustration of the

96 importance of diadromous fishes, in France their landings accounted for $75 \%$ of total income of the

97 commercial inland fishery at the end of the $20^{\text {th }}$ century (Champion 1999; Boisneau and

98 Mennesson-Boisneau 2001). Historically, Acipenser sturio fishing and caviar production used to be

99 an important industry at the beginning of the $20^{\text {th }}$ century (Castelnaud 2011). Later, European eel

100 (Anguilla anguilla) was the most important species landed in value in the Bay of Biscay

101 (Castelnaud 2000) in the early 2000s, especially because of the high market value of glass eels

102 (Ringuet et al. 2002; Briand et al. 2007). Other species have a more limited value when compared to

103 marine species, however they may be of regional importance. Allis shad (Alosa alosa) and to a 
Author-produced version of the article published in Environmental Management, 2018, 61(4), $671-686$

The original publication is available at https://link.springer.com/

doi : 10.1007/s00267-017-0992-3

104 minor extent twait shads (Alosa fallax) are harvested in continental waters throughout their range

105 though their market value has decreased because of abundance decline (Bagliniere et al. 2003).

106 Lampreys (Petromyzon marinus and Lampetra fluviatilis) have a long history of commercial fishing

107 because of their gastronomic delicacy (Kelly and King 2001). Atlantic salmon (Salmo salar) is

108 targeted by a high profile recreational fishery, as all over its distribution area (Verspoor et al. 2007).

109 This question of RCR is crucial for diadromous fish restoration. Most freshwater fishes carry out

110 seasonal migrations (Brönmark et al. 2014), however, diadromous fishes must carry out migrations

111 between fresh and marine waters to complete their life cycle (Myers 1949; McDowall 1988). There

112 are three types of diadromous species (McDowall 1988). Anadromous species, such as many

113 salmon, spend most of their growth phase at sea and reproduce in freshwater. On the other hand,

114 catadromous species, such as the European eel, reproduce in marine waters and spend most of their

115 growth phase in continental waters. Finally, amphidromous fishes reproduce in freshwater and share

116 their growth phase between freshwater and marine waters (McDowall 1988). This remarkable life-

117 history behaviour has evolved in many fish groups (Feutry et al. 2013) but many of these species, as

118 more generally most migratory species from the animal kingdom (Sanderson et al. 2006; Berger et

119 al. 2008; Wilcove and Wikelski 2008), are now in decline all over the world (McDowall 1999;

120 Limburg and Waldman 2009). Many factors explain this decline, however river fragmentation due

121 to dams, weirs, flood gates or other physical obstacles has been considered to be one of the main

122 causes both of their decline (Limburg and Waldman 2009). By impairing free-movements from

123 reproduction to growth habitats, obstacles can interrupt fishes life-cycle and have led to their

124 extinction (Salmo salar in the Rhine River, in the Seine River or in the Garonne River for example),

125 or indeed of their confinement in restricted areas of rivers basins (Salmo salar in Loire River, Alosa

126 alosa in the Rhône River and the Garonne River) (Porcher and Travade 1992; Kondolf 1997;

127 Coutant and Whitney 2000; Larinier 2001; Fukushima et al. 2007; Limburg and Waldman 2009;

128 Lawrence et al. 2016). Because of their high economic and cultural values and other goods and

129 services they support (Dams 1987; Citerne 1998, 2004; Limburg and Waldman 2009), RCR has 
130 often focused on diadromous fishes. For example, most WFD fish indicators include a metric based

131 on diadromous species (Breine et al. 2007; Coates et al. 2007; Pont et al. 2009; Delpech et al. 2010;

132 Scholle and Schuchardt 2012) aiming at assessing river continuity, one of the component of

133 ecological quality defined in this directive. Similarly, in France, river classification and the French

134 Blue Infrastructure were mostly based on species of interest including many diadromous fishes.

135 Moreover, many types of fishways, the most common mitigation measure to river fragmentation,

136 have been specifically designed for diadromous species, especially salmonids (Larinier 2001;

137 Noonan et al. 2012). The predominance of diadromous fishes in RCR suggest that some diadromous

138 fishes are good candidates to be considered as "cultural keystone species" as defined by Garibaldi

139 and Turner (2004), i.e. "culturally salient species that shape in a major way the cultural identity of a

140 people". However, RCR for diadromous fishes implies modifications of barriers, or even obstacles

141 removals, while many obstacles also carry strong cultural values and provide many services (Fox et

142 al. 2016). The potential reshaping of ecosystems goods and services provided by diadromous fishes,

143 from market to non-market values, because of their decline and the emerging conflicts with

144 ecosystem goods and services provided by obstacles, are central questions for the future of RCR for

145 diadromous fishes.

\section{RCR for diadromous fishes: inconsistent results and upcoming challenges}

2.1 Restoration of aquatic ecosystems and RCR for diadromous fishes: inconsistent results

150 Though aquatic ecosystem restoration has a long history in Europe and all over the world (Palmer et 151 al. 2014; Morandi et al. 2014), its impacts are often considered mixed (Palmer et al. 2010; Suding 152 2011; Jähnig et al. 2011; Palmer et al. 2014). Several reasons have been proposed to explain these 153 disappointing results. The first reason is the complexity of aquatic ecosystems functioning based on

154 biological, physical and chemical processes and anthropogenic pressures that work at different

155 temporal and spatial scales. This complexity impairs our ability to understand ecosystem 
Author-produced version of the article published in Environmental Management, 2018, 61(4), $671-686$

The original publication is available at https://link.springer.com/

doi : $10.1007 / s 00267-017-0992-3$

156 functioning and challenges our ability to develop appropriate tools to predict and validate the effects

157 of restoration actions (Arthington et al. 2010; Olden et al. 2014; Lamouroux et al. 2015).

158 Additionally, it makes it difficult to implement restoration actions at appropriate temporal and

159 spatial scales (Palmer et al. 2010; Hermoso et al. 2012; Perring et al. 2015). Over and above this

160 complexity, the mixed results of aquatic ecosystem restoration may also be the result of a poor

161 linkage between science and management. This results in gaps in scientific knowledge that would

162 be crucial for managers, in scientific results that are of poor practical use for managers, and

163 conversely, in the under-use of scientific results by managers (Cabin 2007; Palmer 2008; Suding

164 2011).

165 Another barrier to effective restoration is the lack of consideration of the societal context in which

166 restoration programs take place (Hermoso et al. 2012; Wortley et al. 2013). In a review, Wortley et

167 al. (2013) highlighted that socio-economic dimensions had been considered in only a few

168 restoration programs even though Pahl-Wostl et al. (2013) had underlined that the main barriers to

169 effective restoration often arise from the socio-economic context because of diverging and

170 fluctuating objectives among stakeholders (Barthélémy and Souchon 2009; Jørgensen and Renöfält

171 2013; Perring et al. 2015) and unshared spatial and temporal scales at which they consider

172 restoration (Hermoso et al. 2012).

173 Despite long-terms efforts to restore diadromous fishes (the first laws were adopted in the 1700s for

174 salmon: (Brown et al. 2013)), these restoration programs have also had mixed success (Lichatowich

175 and Lichatowich 2001; Lichatowich and Williams 2009). A famous example is the failure of the

176 recovery program of Pacific salmon in the Columbia river, which has been called the world's largest

177 attempt at ecosystem restoration, but resulted in a failure (Lichatowich and Williams 2009).

178 Regulation on fishing activities, construction of fishways and restocking from hatcheries are among

179 the main measures implemented to conserve and restore diadromous fishes. Regarding more

180 specifically RCR for diadromous fishes, the construction of fishways to mitigate the impact of

181 obstacles to migration is the most common mitigation measure. But, fishways can be considered as 
182 half-way measures (Brown et al. 2013), i.e. measures that do not prevent or solve the problem but

183 only mitigate the symptoms, and often have limited efficiency (Noonan et al. 2012). Obstacles

184 removal appears to be much more ecologically efficient (Garcia De Leaniz 2008; Hitt et al. 2012)

185 and is more and more perceived as a critical tool in river restoration in general and migratory fishes

186 in particular (Doyle et al. 2003; Magilligan et al. 2017). However, it raises many more socio-

187 economic questions than half-way measures (Jørgensen and Renöfält 2013; Magilligan et al. 2017)

188 because of the potential loss of recreational benefits or cultural, aesthetic and historical values

189 provided by the obstacle (e.g. historical heritage of mills, artificial reservoirs creates by the dams

190 used for fishing, sailing or canoeing).

191 In light of this, the next section will address the ecological challenges raised by the RCR for

192 diadromous fishes. The following sections will then focus on why RCR for diadromous fishes

193 should not just be treated as an ecological issue and why, on the contrary, we need integrated

194 multidimensional approaches (Barthélémy and Souchon 2009) to achieve legitimate and

195 comprehensive RCR.

2.2 Three upcoming ecological challenges: a need for tools to support decision making at

\section{the appropriate scale}

199 Scientific tools to support decision making are crucial for managers (Palmer 2008; Suding 2011).

200 Consequently, there is a need to develop tools to predict the ecological outcomes of management

201 options. For RCR, this raises three different challenges: (i) the need to work at an appropriate

202 spatial scale, (ii) the need for comprehensive quantification of the impact of obstacles on

203 diadromous fishes, (iii) the need to take these quantifications into account in predictive models. approaches

207 The question of scale is a key one in ecology (Levin 1992; Chave 2013) and a key issue for our 
208 complete understanding of diadromous fish ecology and conservation (McDowall 2008). The

209 impact of river fragmentation is generally studied at three biological scales: individual scale, the

210 population/meta-population scale and the ichthyofaunistic assemblage scale. Though the catchment

211 scale has sometimes been explored for anadromous species (Buchanan and Skalski 2007; Crane

212 2009; Susquehanna River Anadromous Fish Restoration Cooperative 2010), surprisingly, the impact

213 of obstacles on diadromous fishes has generally been assessed either at the individual or at the

214 population scale but focusing on a specific life stage (upstream or downstream migration) and at the

215 obstacle or river section spatial scale. Since population dynamics processes operate at these scales,

216 working at smaller scale can impair the ability to assess the effect of obstacles on diadromous

217 population dynamics and on their viability. This is even more crucial as the dendritic nature of

218 rivers implies that obstacles and restoration actions in specific sites of a catchment interact in

219 complex ways (Fagan 2002; Labonne et al. 2008; Kemp and O’Hanley 2010), and consequently, the

220 effect of several RCR actions is not necessarily equal to the sum of individual restoration effects

221 (Kuby et al. 2005; O’Hanley and Tomberlin 2005; Palmer and Bernhardt 2006). In the light of these

222 kinds of findings, there is clearly a need to upscale RCR for diadromous fishes from a local

223 approach to a catchment scale thereby bringing this form of restoration in line with calls to upscale

224 aquatic ecosystem restoration more generally (Friberg et al. 2017).

\subsubsection{Second challenge: considering indirect impacts of obstacles on diadromous fishes}

227 There is an abundant literature about the impact of obstacles on diadromous fishes. Two types of

228 impacts have mainly been studied: direct mortality due to downstream passage through hydropower

229 facilities, either at the obstacle scale (Travade et al. 1987; Čada et al. 2006; Dedual 2007; Svendsen

230 et al. 2011) or at the river section scale (Blackwell et al. 1998a; McCleave 2001; Buchanan and

231 Skalski 2007; Welch et al. 2008; Rechisky et al. 2009; Holbrook et al. 2011; Pedersen et al. 2012),

232 and fish blockage at upstream migration that impairs or delays the completion of the migration.

233 However, beyond turbine mortality or blockage at upstream migration, obstacles can have other 
234 more indirect impacts such as over-predation, (Agostinho et al. 2012; Drouineau et al. 2015),

235 overfishing (Briand et al. 2003; Garcia De Leaniz 2008), stress, diseases, energetic costs (Budy et

236 al. 2002) or selective pressure (Caudill et al. 2007; Podgorniak et al. 2015).

237 These indirect impacts can be significant. For example, energetic costs can impair reproduction

238 success for eels, salmon or shads, which stop feeding during reproduction migration (Bracken and

239 Kennedy 1967; Quignard and Douchement 1991; Kadri et al. 1995; Bruijs and Durif 2009).

240 Recently, Mateo et al. (2017) showed that obstacles to eel upstream migration can indirectly

241 severely impact spawning stock biomass even without direct mortality. Regarding eel downstream

242 migration, Drouineau et al. (2017) pointed out that indirect impacts are potentially as important as

243 direct impacts and, that they too, should be taken into account in the future when assessing the

244 impact of obstacles. Restricting the impacts of mortality to direct mortality can lead to an

245 inadequate quantification of those impacts and therefore to an inappropriate prioritization of

246 management actions.

\subsubsection{Third challenge: a need for tools to support decision-making}

249 We have seen that RCR for diadromous fishes should be considered at the river basin scale and that

250 indirect impacts of obstacles should not be neglected. At such a large spatial scale, managers need

251 tools to support and prioritize decisions (Doyle et al. 2003; Kemp and O’Hanley 2010). Kemp and

252 O’Hanley (2010) made a review of existing tools to prioritize management actions. They

253 distinguished three main kinds of approaches. Criterion-based approaches used a set of indicators to

254 evaluate the impact of each obstacle independently and, to some extent, to their cumulative impacts

255 (Nunn and Cowx 2012). While these methods are generally easy to implement, they tend to neglect

256 the complexity of river networks and population dynamics. A second family of approaches relies on

257 GIS (Brevé et al. 2014) and more-recently graph theory (Segurado et al. 2013). While these

258 approaches can be applied at a large scale and produce appealing maps to support decision-making,

259 they generally suffer from an improper consideration of fish movements and population dynamics, 
and from a limited ability to describe the impact of obstacles on fishes. The optimisation method

261 (Kuby et al. 2005; O'Hanley and Tomberlin 2005) is a third method which appears very relevant

262 despite a higher computation cost. This is based on a model that quantifies the benefits of different

263 restoration actions on one of several criteria such as available habitats (O'Hanley and Tomberlin

264 2005), but also economic criteria such as minimal loss of hydropower and storage capacity (Kuby et

265 al. 2005). A numerical optimizer can then be used to objectively to find the sets of restorations

266 actions that maximize outcomes (Zheng et al. 2009).

267 Different models can be used in conjunction with the optimizers. A common approach is to use a

268 statistical species distribution model (SDM) that assesses the impact of obstacles on the distribution

269 of diadromous fishes in a river catchment (Segurado et al. 2014; Clavero and Hermoso 2015). This

270 approach is suitable when historical data are available and can be used to prioritize management

271 actions. However, similarly to the call for the development of predictive mechanistic SDM (Keith et

272 al. 2008; Thuiller et al. 2008; Franklin 2010), the development of mechanistic models that combine

273 river fragmentation and diadromous fishes population dynamics is a challenge to predict ecological

274 effectiveness of management measures and support decision-making at the river basin scale. Such

275 models are required to account for population dynamics and fish movement (Letcher et al. 2007).

276 Similarly to SDMs, mechanistic models can provide complementary results to correlative

277 approaches, and enhance predictive ability (Kearney et al. 2010; Rougier et al. 2015).

278 In view of this, there is an obvious need for mechanistic model that accounts for fish movements

279 and population dynamics, dendritic structure of fragmented river networks, direct and indirect

280 impact of obstacles to (i) assess the impact of obstacles at the obstacle scale and at the population

281 scale and to (ii) predict the effect of restoration actions. These models can then be coupled with an

282 optimization tool to support decision-making.

\subsection{RCR and diadromous fishes much more than an ecological issue}


Author-produced version of the article published in Environmental Management, 2018, 61(4), $671-686$ The original publication is available at https://link.springer.com/

doi : $10.1007 / \mathrm{s} 00267-017-0992-3$

286 In addition to the increasing numbers of regulation on ecological continuity that target diadromous

287 fishes, many kinds of regulation, implemented at different spatial scales, also target diadromous

288 fishes. For example, the Natural Habitats (Natura 2000) Directive (92/43/EEC), a directive that

289 aims at protecting biodiversity, imposes on each MS of the EU to draw up a list of sites hosting

290 natural habitats and wild fauna and flora of interests. Many diadromous fishes are part of the list of

291 species of interest: for example, sturgeon (Acipenser sturio), shads (Alosa alosa and Alosa fallax)

292 and lampreys (Petromyzon marinus and Lampetra fluviatilis). Diadromous fishes conservation is

293 also targeted by international measures or recommendations: for example, the North Atlantic

294 Salmon Conservation Organization recommendations, the Bern Convention on the conservation of

295 European wildlife and natural habitats, the Bonn Convention on the Conservation of Migratory

296 Species of Wild Animals) or Life projects (LIFE Project on shad 2007-2010; Life+ project on shad 297 2011-2014). Regarding eels, the European Eel Regulation (1100/2007 CE) imposes a new set of

298 measures on MSs designed to reverse the decline of the European eel (Anguilla anguilla) population

299 by decreasing all sources of anthropogenic mortality, including impacts of obstacles on migration.

300 Regulations have also been implemented at lower scales. In France, six water agencies manage

301 water in regional hydrographic districts. They coordinate the district master plan for water

302 management (SDAGE, "schéma d'aménagement et de gestion des eaux") - a planned and concerted

303 water management tool at the basin scale- and river basin water management plans (SAGE,

304 Schémas d'Aménagement et de Gestion des Eaux) at the river basin scale (Richard et al. 2010). At

305 this scale, committees for the management of migratory fish (COGEPOMI COmite de GEstion des

306 POissons MIgrateurs) are in charge of the management of diadromous fishes through the

307 implementation of migratory fish management plans (PLAGEPOMI/ PLAn de GEstion des

308 POissons MIgrateurs).

309 Dekker (2016) illustrates the difficulties of this piling up of overlapping regulations and

310 organisations with the example of the European eel. He suggested that the lack of coordination and

311 control between these different regulatory scales is potentially a key explanation for failure to 
312 achieve efficient restoration of this species. This type of hypothesis thus merits detailed analysis

313 mobilising social science discipline research techniques and methods. This is particularly so

314 because challenges emerging from interdependent regulations operating at different scales

315 managing diadromous fishes are neither specific to France nor to Europe. For example, the

316 American eel (Anguilla rostrata) is both managed at the state and the federal scales in Canada and

317 in the United States of America and efforts are made to implement a bi-national management (Haro

318 et al. 2000; MacGregor et al. 2008, 2009). Regarding Atlantic salmon (Salmo salar), management is

319 based on shared stewardship between federal and states governments, First Nations and other

320 Aboriginal organizations, volunteers, other stakeholders and other federal agencies, and Canada is

321 also member of the North Atlantic Salmon Conservation Organization, an international organization

322 aiming at restoring and protecting the Atlantic salmon.

323 All these conservation and restoration regulations potentially interact with one another and,

324 depending on how they are interpreted by policy actors, can cause policy conflicts. For example,

325 some wetlands or lakes created by the construction of a dam are classified by Natura 2000 because

326 of interest for birds or other animals or plants, though they alter fish and sediment free-circulation.

327 But this regulation may conflict with others, for example on water usage. For example, at the

328 European scale, Directive 2009/28/CE promotes the use of renewable energy, including

329 hydropower, though hydropower facilities are often an obstacle to fish free-movement and a source

330 of mortality to migrant species (Blackwell et al. 1998b; Muir et al. 2006; Larinier 2008; Pedersen et

331 al. 2012). RCR also potentially comes into conflict with regulations on the spreading of alien

332 species and diseases (Rahel 2013; McLaughlin et al. 2013; Tullos et al. 2016). Rahel (2013)

333 provides many interesting examples on how fragmentation was used by managers to prevent the

334 spread of diseases in Norway, Czech Republic or United States. In Europe, this issue is especially

335 important for fish farming aquaculture: the European Directive 2006/88/CE defines the condition

336 that should be fulfilled for a zone to be considered as "disease-free", granting specific facilities for

337 aquaculture. Such a zone may either be one or several entire catchments, or a sub-part of the 
catchment delimited by "a natural or artificial barrier that prevents the upward migration of aquatic animals". Consequently, restoring connectivity and migration may question the disease-free status granted to Finnish, Swedish, Irish, Danish or British areas (European Commission Decision of 15

341 April 2010). Finally, RCR may interfere with other water usage regulation, especially rules about

342 minimum discharge and water extraction.

343 Grabosky (1995) mentioned 7 types of potential interactions amongst regulations ranging from

344 synergy to neutralisation. Understanding interactions between conservation regulation and other

345 public policy rules is therefore crucial for offering a comprehensive understanding of why RCR

346 measures can be ineffective. This point has been recently recognised by the European Commission

347 in its encouragement of the integration of ecosystem restoration agenda within the delivery of major

348 policy objectives, especially regional development (rural or urban). For example, the 2020 Strategy

349 for biodiversity and the "Green Infrastructure" both call for a better integration of environment

350 preservation policy within other public policies on territorial development to achieve a better

351 reconciliation of environmental and socio-economic targets. Yet, this question of interdependent

352 regulation goes far beyond a simple ignorance of potential interactions: depending on territories,

353 stakeholders might choose to favour a policy to the detriment of another one for political reasons.

354 For these reasons too RCR should not be analysed in a vacuum but integrated within broader social

355 science evaluations of tensions between public policies and local territorial projects (Carter et al.

356 submitted; Friberg et al. 2017). This also explains why 'one size fits all' strategies do not work to

357 achieve effective RCR for diadromous fishes.

2.3.2 RCR and diadromous fishes and territorial development: competitions of ecosystems goods and services

361 Though river connectivity is an ecological concept, RCR is not only an ecological issue but also a 362 socio-economic issue (Pahl-Wostl et al. 2007; Hermoso et al. 2012; Pahl-Wostl et al. 2013; Wortley 363 et al. 2013; Olden et al. 2014; Barthélémy and Armani 2015), especially because of the multitude of 
goods and services provided by rivers. In a context of climate change and increasing tensions about

\section{Stakeholders, Public authorities}

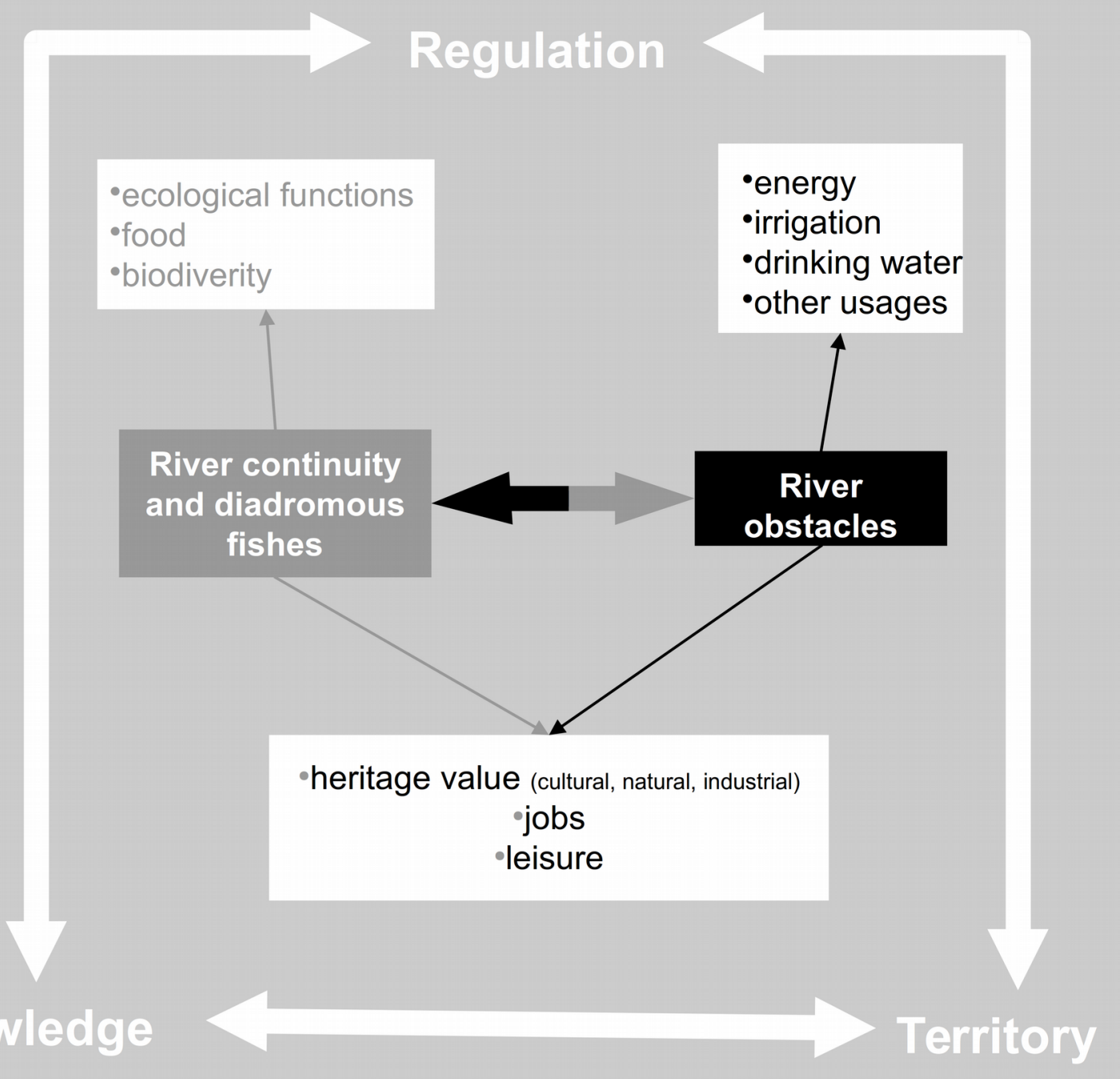

Figure 1. Context of river continuity restoration. Both diadromous fishes (dark grey box) and river obstacles (black box) potentially provide ecosystem goods and services (white boxes). The hierarchy given by actors to these competing ecosystem goods and services - and which may change over time - results from political work between stakeholders and public authorities over knowledge, territory and regulation interdependencies. 
- Assessing ecosystems goods and services supported by diadromous fishes

369 About ten years after the Millennium Assessment, the EU biodiversity strategy for 2020 emphasised

370 goods and services provided by healthy ecosystems (EU Commission 2011). For example, Target 2

371 of the EU strategy was aimed at maintaining and restoring ecosystems and their services. In meeting

372 this target, MSs are required to develop a framework to map and assess ecosystem states and their

373 services and to better integrate the value of ecosystem services into national and EU accounting and

374 reporting systems (EU Commission 2011). Ecosystem goods and services tend to become the

375 quantitative tool to integrate biodiversity into other sectoral policies that may be used to support

376 decision-making (Turner et al. 2000; Daily et al. 2009; de Groot et al. 2010), to arbitrate trade-offs

377 between services provided by services (Maes et al. 2012) but also with goods and services provided

378 by other sectoral activities. As such, ecosystem goods and services can be used as a tool to arbitrate

379 the trade-offs among interdependent activities impacted by the RCR (Figure 1).

380 However, this raises specific challenge for diadromous fishes. Diadromous fishes provide four types

381 of ecosystem goods and services (Limburg and Waldman 2009): (i) provisioning of proteins and

382 other products because of their historic abundance and high catchability during migration, (ii) a

383 transfer of proteins between marine and continental ecosystems as illustrated by the decomposition

384 of salmon carcasses that contribute to the development of riparian vegetation, (iii) supporting the

385 marine food-web and (iv) an important contribution to both indigenous and non-indigenous culture.

386 These species used to have high market value (McDowall 1988, 1999), but the total income of the

387 commercial inland fishery has strongly declined because of the collapse of populations (Champion

388 1999; Boisneau and Mennesson-Boisneau 2001). Meanwhile, other goods and services provided by

389 diadromous fishes, such as cultural services, are potentially becoming more prominent and the

390 value of diadromous fishes should not be restricted to their commercial value. Therefore, there is a

391 need to quantify and qualify new emerging non-market values such as cultural, recreational and/or

392 territorial values. For example, McClenachan et al. (2015) pointed out that the economic benefit in a 
case of alewives restoration was only a small portion of the overall social benefits for stakeholders.

394 While the turnover generated by the fishery used to be more or less proportional to catches, and

395 therefore to fish abundance, the relationship between fish abundance and the quantity of cultural or

396 recreational value they provide is less obvious. The dramatic decline in the market values of

397 diadromous fishes urges (i) updating the ecosystem goods and services directly associated with

398 diadromous fishes and obstacles (ii) based on traditional methods used to quantify non-market

399 ecosystem goods and services, developing a method to assess ecosystem goods and services

400 provided by diadromous fishes and RCR. This framework could be developed around well-honed

401 methods to elicit non-market values, such as choice experiment analysis (Adamowicz et al. 1998;

402 Cameron et al. 2002; List et al. 2006) and could take into account both their uses evolution

403 including economic/productive and environmental, and stakeholders' needs and expectations. Then,

404 indirect goods and services impacted by RCR could be listed and quantified and the relationship

405 between fish abundance and quantity of services elicited.

406 This challenge is crucial to carry out costs-benefit analysis of RCR for diadromous fishes, and

407 consequently to support decision-making.

- Understanding the social construction of RCR to identify political opportunities and points of tension

411 Whereas, as we have argued, public policies and regulation play a critical role in structuring RCR

412 actions, in fact knowledge gaps exist concerning political processes leading to their implementation

413 which are often invisible in practice and little studied in the literature. Indeed, few studies have

414 focused expressly on the link between ecosystem restoration and the politics of implementation of

415 public policy (Baker and Eckerberg 2013). Even less have focused on ecosystem restoration as a

416 territorial project (Germaine and Barraud 2014; Germaine and Lespez 2014). A critical challenge is

417 grasping RCR analytically as a social construction. On the one hand, scholarship has shown the

418 limits of functionalist accounts linking actors' incentives to policy contents: it is not possible to 
419 explain the origins and contents of policies based purely on their functions (Bartley 2007).

420 To illustrate this point, we can argue that from a functionalist perspective, the EU WFD and Blue

421 and Green infrastructure are the results of the functional imperatives of European and French

422 authorities to restore ecological continuity, therefore the efficiency of this measure will be directly

423 assessed regarding economical or ecological outcomes, as in a DPSIR framework (OECD 1993;

424 Gari et al. 2015). By comparison, from a constructivist approach, both the formulation and the local

425 implementation of the WFD and the Green and Blue Infrastructure result from complex political

426 action of many actors (European and French public authorities, local stakeholders, scientists...), and

427 their contents must be explained as contingent 'settlements of conflicts' (Bartley 2007) over both

428 ecological continuity and potentially also other regulations. This is because actors' interests are

429 neither fixed nor can they be assumed: rather they are built in interaction with others' and are

430 socially constructed (Eckersley 2004). In the case of RCR, through their collective interaction over

431 policy implementation, actors' interests and understandings of fish, obstacles and rivers can

432 transform and change.

433 On the other hand, RCR is not disconnected from other political projects but takes place in relation

434 to other territorial projects and river management plans. Conflicts and tensions can emerge between

435 industrial actors and public policies (e.g. when RCR causes tensions with sectoral policy objectives)

436 and over the relative importance of RCR for a community (e.g. in some places RCR has been

437 viewed favourably, McClenachan et al 2015; in others not, Fox et al, 2010). For example, the

438 opposition of fish farmers to RCR does not necessarily relate to the direct issue of ecological

439 continuity but to a connected issue of disease dispersal in river networks. Therefore, constructivist

440 approaches postulate that the link between a public authority, an official objective and a regulation

441 is not a linear one, and must be analysed in a more comprehensive way, and may change through

442 time. This understanding is necessary to identify tensions and and incentives to achieve efficient

443 reviews.

444 To provide critical understandings about the social construction of interests towards RCR and their 
Author-produced version of the article published in Environmental Management, 2018, 61(4), $671-686$

The original publication is available at https://link.springer.com/

doi : 10.1007/s00267-017-0992-3

445 outcomes, including how actors mange potentially conflicting policy processes, research can

446 usefully draw upon the well-honed concept of 'political work' (Jullien and Smith 2014) used in

447 public policy analysis. Political work is defined as action by public and collective private actors to

448 translate their immediate local concerns into public problems and which demand public regulatory

449 responses (e.g. public policies). Political work involves a number of activities including the making

450 of arguments to put issues on the political agenda ; the forging of alliances with other actors ; the

451 establishment of new decisional structures ; strategies of mediatisation and public speeches

452 advancing and justifying actor positions held. Actors' political work can be aimed at putting in place

453 new public policies, implementing public policies already in place, changing public policies,

454 countering public policies. As an illustration, in the context of the RCR, the political work of some

455 NGOs over RCR can consist in strategies to promote the restoration of continuity in opposition to

456 other stakeholders, while at the same time promoting the development of renewable sources of

457 energy in the context of energy transition. These links are crucial, especially in the current period of

458 increasing involvement of local stakeholders in river management after decades of distant

459 relationships (Zylberblat et al. 1996; Blackstock and Richards 2007; Pahl-Wostl et al. 2007;

460 Germaine and Barraud 2014). Studying political work can therefore enable research to generate

461 understandings about how successful RCR projects came to be successful (i.e. going beyond the

462 question of social benefits of projects once implemented) and/or about lines of conflict and tension

463 which require to be addressed to bring about future change.

464 In a regulatory context, when the EU biodiversity strategy for 2020 (EU Commission 2011) calls

465 for a better integration of biodiversity protection into major public policies, social science can and

466 should provide valuable insights on how RCR impacts on-going territorial construction processes

467 led by different or competing actors at different scales and whether RCR is altering peoples'

468 relations to rivers and diadromous fish. This is a critical point, especially responding to climate

469 change and increasing tensions around water use that may modify choices and priorities. For

470 example, the decline of the abundance of diadromous species may either lead to a reinforcement of 
471 management actions (McClenachan et al. 2015) or to a loss of societal interest for these fish leading

472 to loss of oversight of their decline. This last threat was defined as "ecosocial anomie" by Limburg

473 and Waldman (2009). But, we contend, to assess whether migratory fish hold any cultural value will

474 require social science analysis of political work of actors on RCR in different places compared. The

475 example of the Scottish fishery (Carter 2014) is a very instructive example of a largely

476 unpredictable mobilization of actors through political work that lead to deep modification of

477 management and sustainable fisheries. Also within the example of Scottish-EU fisheries, Carter

478 (2013) demonstrated how insights from constructivist approaches can identify lines of tension

479 blocking implementation as well as opportunities for major change. Building on such approaches, a

480 challenge to achieve effective RCR is to map political work socially constructing RCR for

481 diadromous fishes, by describing actors networks, arguments, expectations and preferences over

482 time. This task is required to elicit formal and informal links between stakeholders and how they

483 manage interdependencies between possible divergent policy objectives, between territories and

484 between knowledge forms (Carter et al. submitted). By doing this, research can identify the 'type'

485 of political work around RCR and diadromous fishes; 'how' and 'why' incentives and conceptions

486 of restoration and ecosystem services' values may vary and the consequences for effective

487 integration in particular territories. In so doing, it can point out the for legitimate RCR, conflicts

488 blocking effective implementation, and potentially new types of incentives to achieve effective

489 RCR.

2.4 Proposing tools to move beyond traditional disciplinary frontiers and achieve a

493 multidimensional approach to RCR

$494 \quad$ 2.4.1 Organising knowledge flows between disciplines

495 We have listed three types of challenges in three different fields and which more or less correspond 496 to three groups of disciplines: ecology, environmental economics and geography/political science 
497 around the question of RCR and diadromous fishes (Figure 2). Each discipline provides unique

498 insights on RCR. However, a comprehensive analysis requires that these insights are collectively

499 organised in a coherent way. This is especially true since each discipline needs the results provided

500 by the others for effective RCR evaluation. Consequently, it is important to acknowledge that

501 disciplines are interdependent.

502

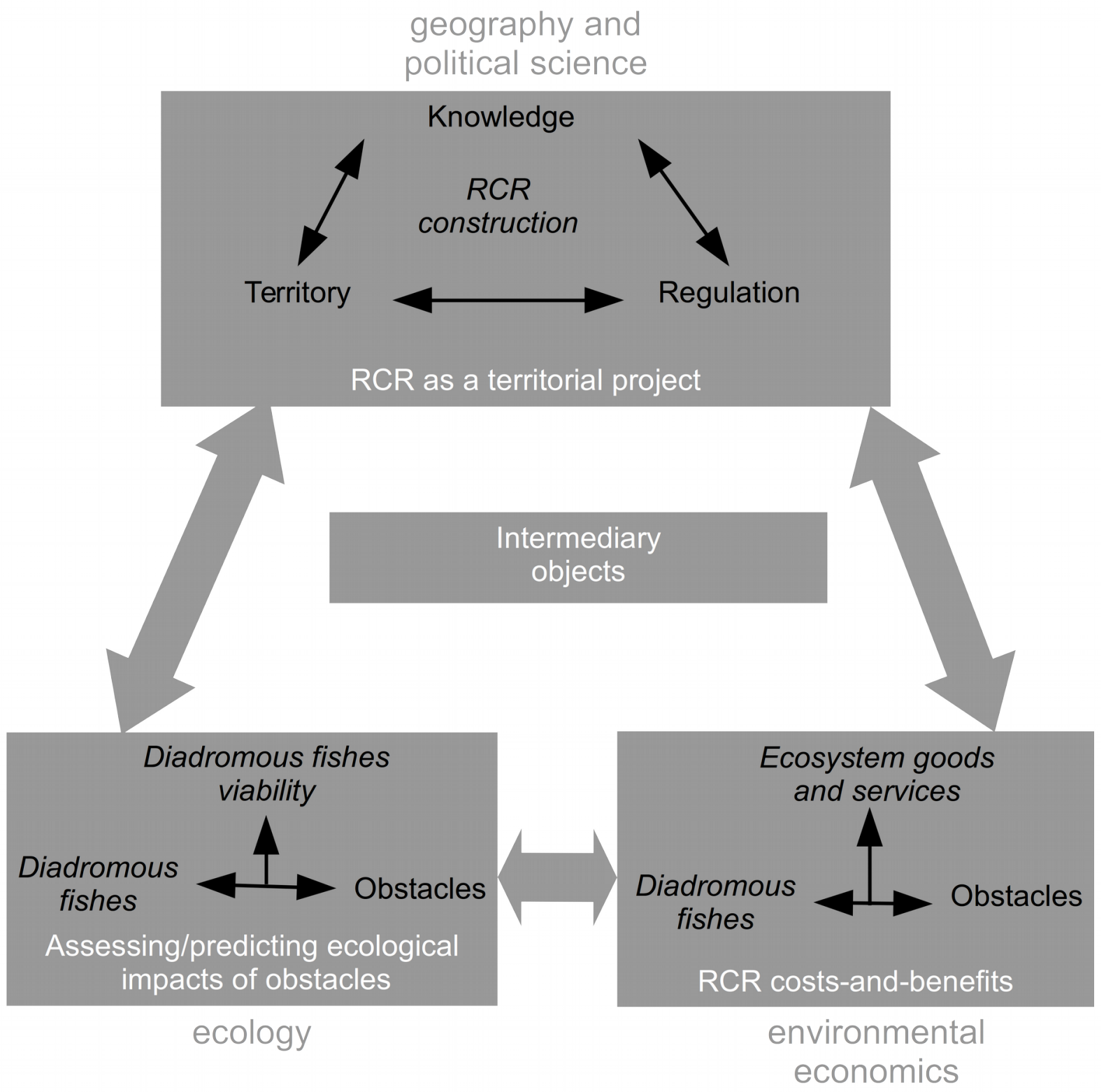

Figure 2. Conceptualising, evaluating and achieving RCR for diadromous fishes require interdisciplinary exchanges. Each discipline can provide different results (ecology: quantification of the ecological outcome of restoration, environmental economics: valuation in terms of ecosystem 
Author-produced version of the article published in Environmental Management, 2018, 61(4), $671-686$ The original publication is available at https://link.springer.com/

doi : 10.1007/s00267-017-0992-3

goods and services, geography and political science: regulation, territories, actors and political work, specifying actors and arguments either 'in favour', 'against' or 'indifferent' to RCR).

505 Ecology is required to quantify and predict the effect of RCR on the abundance of diadromous

506 fishes. Through the economical quantification of market and non-market values of diadromous

507 fishes, their abundance can then be converted into goods and ecosystem services that can be used to

508 manage trade-off between conflicting services. To elicit and understand these trade-offs and their

509 shifts through time, geographers and political scientists can provide insights on the social

510 construction of the restoration program and more specifically of the objectives of the different

511 stakeholders and the temporal and spatial scales of political activity in territories. In turn, this

512 analysis of the social construction of RCR requires spatial information on ecological factors (such

513 as the spatial zones of ecological importance, the ecological importance of species or their

514 interactions with other species) and economical ones (for example, economic valuation of services

515 of services).

516 To organise the necessary exchange of knowledge and moreover, the sharing of assumptions among

517 disciplines, we propose using cross-disciplinary knowledge flows (Figure 2). These are flows of

518 questions and results and visions of the problems encountered by each discipline and which are

519 communicated to the others. This does not necessarily happen spontaneously. To facilitate the

520 process, we propose working with "intermediary objects" (Vinck 1999). In collaborative networks,

521 intermediary objects refer to objects that are meaningful for all actors of the network, though their

522 meaning can vary among actors (Vinck and Jeantet 1995; Vinck 1999; Boujut and Blanco 2003;

523 Eckert and Boujut 2003; Vinck 2003; El-Kechai and Choquet 2006). They have proved to be

524 valuable mediation tools among disciplines or domains, enhancing communication among them by

525 facilitating translation and a support to share a representation of problems (Boujut and Blanco 2003;

526 Buller 2009). Typically, in the case of the RCR, since spatial and temporal scales are especially

527 important, maps and timelines are among the most relevant intermediary objects. The co- 
Author-produced version of the article published in Environmental Management, 2018, 61(4), $671-686$

The original publication is available at https://link.springer.com/

doi : 10.1007/s00267-017-0992-3

528 construction of maps is a way to share visions of territories: each discipline can show on a same tool

529 where and why specific zones are of interest (spawning grounds, administrative delimitation,

530 implantation of an enterprise, conflicts...). Regarding a map of obstacles, while the geographical

531 position is common to any discipline, the attributes of interest for the different disciplines are

532 different (for example, passability in ecology, turnover in economy, cultural value in geography).

533 Maps of actors are also useful tool for identifying the role and importance of different stakeholders

534 and public authorities form a multidimensional perspective. Building a multidimensional timeline is

535 a way to establish relationship between events from different fields. Listing and co-constructing

536 intermediary objects can therefore be useful to achieve a comprehensive view of RCR in territories.

\subsubsection{Addressing the complexity of spatial and temporal scalar interactions}

539 We outlined earlier the major importance of time and space for restoration programs. Consequently

540 scale integration is a major challenge in a multidisciplinary approach of RCR. Regarding

541 diadromous fishes and RCR, the river basin scale seems to be a central integrative scale. This is

542 both an ecological (population or sub-population scale) and physical/hydrological scale. The river

543 catchment scale also corresponds to water administrative units. Hydrographic districts were

544 introduced in the context of the Water Framework Directive, and correspond to one or several

545 adjacent river basins in which MSs were required to implement River Basin Management Plans

546 (presently, the plans cover the period 2009-2015). Finally, river basins tend also to be a political

547 unit. Water and its governance is a cornerstone issue in the territorialisation process (Ghiotti 2006)

548 and the notion of basin common principle is a key argument in many political constructions. For

549 example, each Water Agency in France has articulated a specific understanding of the river basin

550 common interest (Meublat and Lourd 2001; Bouleau 2014). In this context, the basin scale appears

551 to be the landscape scale advocated by Perring et al. (2015) when calling for a scaling-up of

552 restoration activities. It appears to be a unit scale common to the multiple dimensions involved in

553 RCR. However, it will be necessary to understand how this central scale interacts with other spatio- 
554 temporal scales to achieve effective RCR for diadromous fishes. For example, while a river

555 catchment is a water administrative unit, it does not match the geographical scale of administrative

556 regions, nor other issues which are relevant for territorial development such as the governing of

557 agriculture or fish farming. Moreover, the definition of basin might vary depending on questions

558 and mobilizations (Fernandez et al. 2014; Bréthaut and Pflieger 2015). In this context of interacting

559 scales in multiple dimensions, scale should not be seen only as an "euclidean distance" or

560 "temporal-distance", but also as a relational concept which sees space as the result of sociological,

561 ecological or biospherical relationships (Healey 2004). Places, sites and territories are not seen as

562 geographical units but as a social-construct with meanings specific to the social context. The co-

563 construction of intermediary objects such as maps, networks of actors and timelines should favour

564 the understanding of scalar interactions around the river catchment scale. This is particularly

565 important as the challenges of scalar interactions are not, as is sometimes implied, merely a matter

566 of coordination, and being legitimate at one scale does not necessarily mean being legitimate at

567 another (Carter et al. submitted).

570 A specific challenge emerges bringing about knowledge flows in the case of RCR. This is because

571 whereas ecological and economic valuations are frequently based on functionalist approaches, this

572 is not necessarily the case for political science and geography. As we have argued, it has been well

573 documented that river restoration is a social construction. Recognising this is especially important

574 for building multidisciplinary evaluations of effectiveness. Since RCR is a social construction, an

575 example of success or failure in one territory does not mean that the same approach would

576 necessarily have had the same results in an other context: "one size does not fit all". For example,

577 Blackstock et al. (2012) have shown that the process of implementing a program can be just as

578 important for stakeholders as its outputs and, moreover, that effectiveness of outputs is directly

579 associated by stakeholders with effectiveness of inputs. 
580 Although all disciplines recognize the need for multiscalar and multidimensional approaches, the

581 integration between functionalist and constructivist approaches is not straightforward because of

582 ontological and methodological differences. Traditional frameworks support restoration planning,

583 such as DPSIR and related frameworks (OECD 1993; Gari et al. 2015) or PCDA (Plan-Do-Check-

584 Act) are generally based on linear causal relationships from an anthropogenic pressure to the

585 implementation of a restoration measure. These functionalist approaches, consistent with some

586 ecological and economical ontologies, have proved to be useful and efficient to describe systems

587 and provide tools to support restoration planning. However, they loose their usefulness as soon as

588 they confuse their simplified and static version of the world with an accurate description of reality.

589 This is even more critical when evaluating the effectiveness of RCR since initial objectives and 590 causal links may have changed through time.

591 Consequently, there is a need for new frameworks that aim to conciliate the constructivist point of

592 view as upheld in some strands of political science and geography with the more functionalist

593 approach of natural and economic science. It is not only a methodological challenge that would

594 consist in lining up deliverables of a different nature (especially quantitative and qualitative results)

595 but the development of a new framework based on two antagonistic ontologies, to achieve effective

596 RCR for diadromous fishes. Once again, the co-construction of cross-disciplinary knowledge flows

597 and intermediary objects can be critical elements of such frameworks to elicit, and hence make

598 visible, complementarities between different ontologies.

\section{Acknowledgments}

601 We would like to thank Christian Rigaud, Clarisse Cazals and Guy Verreault for fruitful discussions, 602 and three anonymous referees for their constructive comments.

603

\section{Literature Cited}

Adamowicz W, Boxall P, Williams M, Louviere J (1998) Stated Preference Approaches for 
Measuring Passive Use Values: Choice Experiments and Contingent Valuation. Am J Agric Econ 80:64-75 . doi: 10.2307/3180269

Agostinho AA, Agostinho CS, Pelicice FM, Marques EE (2012) Fish ladders: safe fish passage or hotspot for predation? Neotropical Ichtyology 10:687-696

Amoros C, Roux AL (1988) Interaction between water bodies within the floodplains of large rivers: function and development of connectivity. Münst Geogr Arb 29:125-130

Araújo F, Pinto B, Teixeira T (2009) Longitudinal patterns of fish assemblages in a large tropical river in southeastern Brazil: Evaluating environmental influences and some concepts in river ecology. Hydrobiologia 618:89-107

Arthington AH, Naiman RJ, McCLAIN ME, Nilsson C (2010) Preserving the biodiversity and ecological services of rivers: new challenges and research opportunities. Freshw Biol 55:116 . doi: $10.1111 / \mathrm{j} .1365-2427.2009 .02340 . \mathrm{x}$

Bagliniere J-L, Sabatié MR, Rochard E, et al (2003) The allis shad Alosa alosa: biology, ecology, range, and status of populations. Am Fish Soc Symp 35:85-102

Baker S, Eckerberg K (2013) A policy analysis perspective on ecological restoration. Ecol Soc $18: 17-27$

Barthélémy C, Armani G (2015) A comparison of social processes at three sites of the French Rhône River subjected to ecological restoration. Freshw Biol 60:1208-1220 . doi: 10.1111/fwb.12531

Barthélémy C, Souchon Y (2009) La restauration écologique du fleuve Rhône sous le double regard du sociologue et de l'écologue. Nat Sci Sociétés 17:113-121 . doi: 10.1051/nss/2009025

Bartley T (2007) Institutional emergence in an era of globalization: the rise of transnational private 
Author-produced version of the article published in Environmental Management, 2018, 61(4), $671-686$ The original publication is available at https://link.springer.com/

doi : 10.1007/s00267-017-0992-3

regulation of labour and environmental conditions. Am J Sociol 113:297-351

Basset A, Barbone E, Elliott M, et al (2013) A unifying approach to understanding transitional waters: Fundamental properties emerging from ecotone ecosystems. Estuar Coast Shelf Sci 132:5-16 . doi: 10.1016/j.ecss.2012.04.012

Berger J, Young JK, Berger KM (2008) Protecting Migration Corridors: Challenges and Optimism for Mongolian Saiga. PLoS Biol 6:1365-1367 . doi: 10.1371/journal.pbio.0060165

Blackstock KL, Richards C (2007) Evaluating stakeholder involvement in river basin planning: a Scottish case study. Water Policy 9:493

Blackstock KL, Waylen KA, Dunglinson J, Marshall KM (2012) Linking process to outcomes Internal and external criteria for a stakeholder involvement in River Basin Management Planning. Ecol Econ 77:113-122 . doi: 10.1016/j.ecolecon.2012.02.015

Blackwell B, Gries G, Juanes F, et al (1998a) Simulating migration mortality of Atlantic salmon smolts in. Merrimack River North Am J Fish Manage 1831-45

Blackwell B, Gries G, Juanes F, et al (1998b) Simulating migration mortality of Atlantic salmon smolts in the Merrimack River. North Am J Fish Manag 18:31-45

Bloom DD, Lovejoy NR (2014) The evolutionary origins of diadromy inferred from a timecalibrated phylogeny for Clupeiformes (herring and allies). Proc R Soc B Biol Sci 281:20132081 . doi: 10.1098/rspb.2013.2081

Boisneau P, Mennesson-Boisneau C (2001) Inland commercial fisheries management in France. Fish Manag Ecol 8:303-310 . doi: 10.1111/j.1365-2400.2001.00255.x

Boujut J-F, Blanco E (2003) Intermediary objects as a means to foster co-operation in engineering design. Comput Support Coop Work CSCW 12:205-219 
Bouleau G (2014) The co-production of science and waterscapes: The case of the Seine and the Rhône Rivers, France. Geoforum 57:248-257 . doi: 10.1016/j.geoforum.2013.01.009

Bracken J, Kennedy M (1967) Notes on some Irish estuarine and inshore fishes

Breine JJ, Maes J, Quataert P, et al (2007) A fish-based assessment tool for the ecological quality of the brackish Schelde estuary in Flanders (Belgium). Hydrobiologia 575:141-159 . doi: $10.1007 / \mathrm{s} 10750-006-0357-\mathrm{z}$

Bréthaut C, Pflieger G (2015) The shifting territorialities of the Rhone River's transboundary governance: a historical analysis of the evolution of the functions, uses and spatiality of river basin governance. Reg Environ Change 15:549-558 . doi: 10.1007/s10113-013-0541-4

Brevé NWP, Buijse AD, Kroes MJ, et al (2014) Supporting decision-making for improving longitudinal connectivity for diadromous and potamodromous fishes in complex catchments. Sci Total Environ 496:206-218 . doi: 10.1016/j.scitotenv.2014.07.043

Briand C, Bonhommeau S, Beaulaton L, Castelnaud G (2007) An appraisal of historical glass eel fisheries and markets: landings, trade routes and future prospect for management. Inst. Fish. Manag. Annu. Conf.

Briand C, Fatin D, Fontenelle G, Feunteun E (2003) Estuarine and fluvial recruitment of the European glass eel, Anguilla anguilla, in an exploited Atlantic estuary. Fish Manag Ecol 10:377-384 . doi: 10.1111/j.1365-2400.2003.00354.x

Brönmark C, Hulthén K, Nilsson PA, et al (2014) There and back again: migration in freshwater fishes. Can J Zool 92:467-479 . doi: 10.1139/cjz-2012-0277

Brown JJ, Limburg KE, Waldman JR, et al (2013) Fish and hydropower on the U.S. Atlantic coast: failed fisheries policies from half-way technologies. Conserv Lett 6:280-286 . doi: $10.1111 /$ conl.12000 
Bruijs MCM, Durif CMF (2009) Silver Eel Migration and Behaviour. In: Thillart G van den,

Dufour S, Rankin JC (eds) Spawning Migration of the European Eel. Springer Netherlands, pp 65-95

Buchanan R, Skalski J (2007) A migratory life-cycle release-recapture model for Salmonid PIT-tag investigations. J Agric Biol Environ Stat 12:325-345

Budy P, Theide G, Bouwes N, et al (2002) Evidence linking delayed mortality of Snake River salmon to their earlier hydrosystem experience. North Am J Fish Manag 22:35-51

Buller H (2009) The lively process of interdisciplinarity. Area 41:395-403 . doi: 10.1111/j.14754762.2008.00856.x

Cabin RJ (2007) Science-Driven Restoration: A Square Grid on a Round Earth? Restor Ecol 15:1-7

Čada G, Loar J, Garrison L, et al (2006) Efforts to reduce mortality to hydroelectric turbine-passed fish: Locating and quantifying damaging shear stresses. Environ Manage 37:898-906

Cameron TA, Poe GL, Ethier RG, Schulze WD (2002) Alternative non-market value-elicitation methods: are the underlying preferences the same? J Environ Econ Manag 44:391-425

Carter C (2013) Constructing sustainability in EU fisheries: Re-drawing the boundary between science and politics? Environ Sci Policy 30:26-35 . doi: 10.1016/j.envsci.2012.11.015

Carter C (2014) The transformation of Scottish fisheries: Sustainable interdependence from 'net to plate.' Mar Policy 44:131-138

Carter C, Bouleau G, Le Floch S, Gassiat A (submitted) The policy and social dimension of restoration thinking: Paying greater attention to interdependencies in restoration governing practice. In: Social issues in river restoration projects: interdisciplinary perspectives from researchers and practitioners. Wiley Publications 
Castelnaud G (2000) Localisation de la pêche, effectifs de pêcheurs et production des espèces amphihalines dans les fleuves français. Bull Fr Pêche Piscic 357/358:439-460

Castelnaud G (2011) Sturgeon Fishing, Landings, and Caviar Production During the Twentieth Century in the Garonne Basin and the Coastal Sea. In: Williot P, Rochard E, Desse-Berset N, et al. (eds) Biology and Conservation of the European SturgeonAcipenser sturioL. 1758. Springer Berlin Heidelberg, pp 177-193

Caudill C, Daigle W, Keefer M, et al (2007) Slow dam passage in adult Columbia River salmonids associated with unsuccessful migration: Delayed negative effects of passage obstacles or condition-dependent mortality? Can J Fish Aquat Sci 64:979-995

Champion L (1999) Etude socio-économique des pêches professionnelles continentales. Rapp CNAPPEDCSPMin Agric Pêch-CORRAIL Nantes

Chave J (2013) The problem of pattern and scale in ecology: what have we learned in 20 years? Ecol Lett 16:4-16 . doi: 10.1111/ele.12048

Citerne P (1998) Le thème du poisson dans l'art paléolithique des Pyrénées. Bull Société Préhistorique Ariège 53:17-64

Citerne P (2004) Présence de l'esturgeon dans le bestiaire figuré paléolithique: conditions et limites de l'analyse morphologique. Bull Société Préhistorique Ariège-Pyrén 59:71-92

Clavero M, Hermoso V (2015) Historical data to plan the recovery of the European eel. J Appl Ecol 52:960-968 . doi: 10.1111/1365-2664.12446

Coates S, Waugh A, Anwar A, Robson M (2007) Efficacy of a multi-metric fish index as an analysis tool for the transitional fish component of the Water Framework Directive. Mar Pollut Bull $55: 225-240$ 
Coutant CC, Whitney RR (2000) Fish behavior in relation to passage through hydropower turbines: A review. Trans Am Fish Soc 129:351-380

Crane J (2009) "Setting the river free": The removal of the Edwards dam and the restoration of the Kennebec River. Water Hist 1:131

Crook K, Pringle C, Freeman M (2009) A method to assess longitudinal riverine connectivity in tropical streams dominated by migratory biota. Aquat Conserv Mar Freshw Ecosyst 19:714723

Daily GC, Polasky S, Goldstein J, et al (2009) Ecosystem services in decision making: time to deliver. Front Ecol Environ 7:21-28 . doi: 10.1890/080025

Dams LR (1987) Poissons et contours de type pisciforme dans l'art pariétal paléolithique. Bull Société R Belge Anthropol Préhistoire 98:81-132

de Groot RS, Alkemade R, Braat L, et al (2010) Challenges in integrating the concept of ecosystem services and values in landscape planning, management and decision making. Ecol Complex 7:260-272 . doi: 10.1016/j.ecocom.2009.10.006

Dedual M (2007) Survival of juvenile rainbow trout passing through a francis turbine. North Am J Fish Manage 27:181-186

Dekker W (2016) Management of the eel is slipping through our hands! Distribute control and orchestrate national protection. ICES J Mar Sci 73:2442-2452 . doi: 10.1093/icesjms/fsw094

Delpech C, Courrat A, Pasquaud S, et al (2010) Development of a fish-based index to assess the ecological quality of transitional waters: The case of French estuaries. Mar Pollut Bull 60:908-918 
Doyle MW, Harbor JM, Stanley EH (2003) Toward Policies and Decision-Making for Dam Removal. Environ Manage 31:0453-0465 . doi: 10.1007/s00267-002-2819-z

Drouineau H, Bau F, Alric A, et al (2017) Silver eel downstream migration in fragmented rivers: use of a Bayesian model to track movements triggering and duration. Aquat Living Resour 30:1-9 . doi: 10.1051/alr/2017003

Drouineau H, Rigaud C, Laharanne A, et al (2015) Assessing the efficiency of an elver ladder using a multi-state mark-recapture model. River Res Appl 31:291-300 . doi: 10.1002/rra.2737

Eckersley R (2004) The green state: Rethinking democracy and sovereignty. MIT Press

Eckert C, Boujut J-F (2003) The role of objects in design co-operation: communication through physical or virtual objects. Comput Support Coop Work CSCW 12:145-151

El-Kechai H, Choquet C (2006) Understanding the collective design process by analyzing intermediary objects. In: Advanced Learning Technologies, 2006. Sixth International Conference on. IEEE, pp 1047-1051

Elliott M, Hemingway K (2002) Fishes in Estuaries. Blackwell Science, London

Elliott M, Whitfield AK (2011) Challenging paradigms in estuarine ecology and management. Estuar Coast Shelf Sci 94:306-314 . doi: 10.1016/j.ecss.2011.06.016

EU Commission (2011) Our Life in Insurance, our Natural Capital: An EU Biodiversity Strategy to 2020. COM 2011 244:

Fagan W (2002) Connectivity, fragmentation, and extinction risk in dendritic metapopulations. Ecology 83:3243-3249

Fernandez S, Bouleau G, Treyer S (2014) Bringing politics back into water planning scenarios in Europe. J Hydrol 518:17-27 . doi: 10.1016/j.jhydrol.2014.01.010 
Feutry P, Castelin M, Ovenden JR, et al (2013) Evolution of Diadromy in Fish: Insights from a Tropical Genus ( Kuhlia Species). Am Nat 181:52-63 . doi: 10.1086/668593

Forman RTT, Godron M (1986) Landscape ecology. 619 pp. Jhon Wiley Sons N Y

Fox CA, Magilligan FJ, Sneddon CS (2016) "You kill the dam, you are killing a part of me": Dam removal and the environmental politics of river restoration. Geoforum 70:93-104 . doi: 10.1016/j.geoforum.2016.02.013

Franklin J (2010) Moving beyond static species distribution models in support of conservation biogeography. Divers Distrib 16:321-330

Friberg N, Buijse T, Carter C, et al (2017) Effective restoration of aquatic ecosystems: scaling the barriers. Wiley Interdiscip Rev Water 4:n/a-n/a . doi: 10.1002/wat2.1190

Fukushima M, Kameyama S, Kaneko M, et al (2007) Modelling the effects of dams on freshwater fish distributions in Hokkaido, Japan. Freshw Biol 52:1511-1524

Garcia De Leaniz C (2008) Weir removal in salmonid streams: Implications, challenges and practicalities. Hydrobiologia 609:83-96

Gardner C, Coghlan S, Zydlewski J, Saunders R (2013) Distribution and abundance of stream fishes in relation to barriers: Implications for monitoring stream recovery after barrier removal. River Res Appl 29:65-78

Gari SR, Newton A, Icely JD (2015) A review of the application and evolution of the DPSIR framework with an emphasis on coastal social-ecological systems. Ocean Coast Manag 103:63-77 . doi: 10.1016/j.ocecoaman.2014.11.013

Garibaldi A, Turner N (2004) Cultural keystone species: implications for ecological conservation and restoration. Ecol Soc 9:1 
Gergel SE, Carpenter SR, Stanley EH (2005) Do dams and levees impact nitrogen cycling?

Simulating the effects of flood alterations on floodplain denitrification. Glob Change Biol 11:1352-1367 . doi: 10.1111/j.1365-2486.2005.00966.x

Germaine M-A, Barraud R (2014) Les rivières de l'ouest de la France sont-elles seulement des infrastructures naturelles? Les modèles de gestion à l'épreuve de la directive-cadre sur l'eau. Nat Sci Sociétés 21:373-384

Germaine M-A, Lespez L (2014) Le démantèlement des barrages de la Sélune (Manche). Des réseaux d'acteurs au projet de territoire ? Dév Durable Territ Économie Géographie Polit Droit Sociol. doi: 10.4000/developpementdurable.10525

Ghiotti S (2006) Les Territoires de l'eau et la décentralisation. La gouvernance de bassin versant ou les limites d'une évidence. Dév Durable Territ Économie Géographie Polit Droit Sociol. doi: 10.4000/developpementdurable. 1742

Grabosky PN (1995) Governing at a distance: self-regulating green markets. Mark State Environ Macmillan 197-228

Haro A, Richkus W, Whalen K, et al (2000) Population decline of the American eel: implications for research and management. Fisheries 25:7-16

Healey P (2004) The Treatment of Space and Place in the New Strategic Spatial Planning in Europe. Int J Urban Reg Res 28:45-67 . doi: 10.1111/j.0309-1317.2004.00502.x

Hermoso V, Pantus F, Olley J, et al (2012) Systematic planning for river rehabilitation: integrating multiple ecological and economic objectives in complex decisions. Freshw Biol 57:1-9 . doi: 10.1111/j.1365-2427.2011.02693.x

Hitt NP, Eyler S, Wofford JEB (2012) Dam Removal Increases American Eel Abundance in Distant Headwater Streams. Trans Am Fish Soc 141:1171-1179 
Author-produced version of the article published in Environmental Management, 2018, 61(4), $671-686$

Holbrook CM, Kinnison MT, Zydlewski J (2011) Survival of Migrating Atlantic Salmon Smolts through the Penobscot River, Maine: a Prerestoration Assessment. Trans Am Fish Soc $140: 1255-1268$

Horreo JL, Martinez JL, Ayllon F, et al (2011) Impact of habitat fragmentation on the genetics of populations in dendritic landscapes. Freshw Biol 56:2567-2579

Humphries P, Winemiller KO (2009) Historical Impacts on River Fauna, Shifting Baselines, and Challenges for Restoration. BioScience 59:673-684 . doi: 10.1525/bio.2009.59.8.9

Jager H, Van Winkle W, Holcomb B (1999) Would hydrologic climate changes in Sierra Nevada streams influence trout persistence? Trans Am Fish Soc 128:222-240

Jager HI, Chandler JA, Lepla KB, Van Winkle W (2001) A theoretical study of river fragmentation by dams and its effects on white sturgeon populations. Env Biol Fishes 60:347-361

Jähnig SC, Lorenz AW, Hering D, et al (2011) River restoration success: a question of perception. Ecol Appl 21:2007-2015 . doi: 10.1890/10-0618.1

Jørgensen D, Renöfält BM (2013) Damned if you do, dammed if you don’t: debates on dam removal in the Swedish media. Ecol Soc 18:18

Jullien B, Smith A (2014) The EU's government of industries: Markets, institutions and politics. Routledge

Kadri S, Metcalfe NB, Huntingford FA, Thorpe JE (1995) What Controls the Onset of Anorexia in Maturing Adult Female Atlantic Salmon? Funct Ecol 9:790-797 . doi: 10.2307/2390254

Kearney MR, Wintle BA, Porter WP (2010) Correlative and mechanistic models of species distribution provide congruent forecasts under climate change. Conserv Lett 3:203-213

Keith DA, Akçakaya HR, Thuiller W, et al (2008) Predicting extinction risks under climate change: 
coupling stochastic population models with dynamic bioclimatic habitat models. Biol Lett $4: 560-563$

Kelly FL, King JJ (2001) A Review of the Ecology and Distribution of Three Lamprey Species, Lampetra fluviatilis (L.), Lampetra planeri (Bloch) and Petromyzon marinus (L.): A Context for Conservation and Biodiversity Considerations in Ireland. Biol Environ Proc R Ir Acad 101B:165-185

Kemp P, O’Hanley J (2010) Procedures for evaluating and prioritising the removal of fish passage barriers: A synthesis. Fish Manag Ecol 17:297-322

Kondolf G, Boulton A, O’Daniel S, et al (2006) Process-based ecological river restoration:

Visualizing three-dimensional connectivity and dynamic vectors to recover lost linkages. Ecol Soc 11:

Kondolf GM (1997) PROFILE: Hungry Water: Effects of Dams and Gravel Mining on River Channels. Environ Manage 21:533-551

Kuby M, Fagan W, ReVelle C, Graf W (2005) A multiobjective optimization model for dam removal: An example trading off salmon passage with hydropower and water storage in the Willamette basin. Adv Water Resour 28:845-855

Labonne J, Ravigné V, Parisi B, Gaucherel C (2008) Linking dendritic network structures to population demogenetics: The downside of connectivity. Oikos 117:1479-1490 . doi: 10.1111/j.0030-1299.2008.16976.x

Lamouroux N, Gore JA, Lepori F, Statzner B (2015) The ecological restoration of large rivers needs science-based, predictive tools meeting public expectations: an overview of the Rhône project. Freshw Biol 60:1069-1084 . doi: 10.1111/fwb.12553

Larinier M (2001) Environmental issues, dams and fish migrations. In: Dams, fish and fisheries: 
Opportunities, challenges and conflict resolution, FAO fisheries technical paper 419. pp 4590

Larinier M (2008) Fish passage experience at small-scale hydro-electric power plants in France. Hydrobiologia 609:97-108

Lawrence ER, Kuparinen A, Hutchings JA (2016) Influence of dams on population persistence in Atlantic salmon (Salmo salar). Can J Zool 94:329-338

Letcher BH, Nislow KH, Coombs JA, et al (2007) Population response to habitat fragmentation in a stream-dwelling brook trout population. Plos One 2:e1139 . doi: 10.1371/journal.pone.0001139

Levin SA (1992) The Problem of Pattern and Scale in Ecology: The Robert H. MacArthur Award Lecture. Ecology 73:1943-1967 . doi: 10.2307/1941447

Lichatowich J, Lichatowich JA (2001) Salmon Without Rivers: A History Of The Pacific Salmon Crisis. Island Press

Lichatowich JA, Williams RN (2009) Failures to incorporate science into fishery management and recovery programs: lessons from the Columbia River. In: American Fisheries Society Symposium. pp 1005-1019

Limburg KE, Waldman JR (2009) Dramatic Declines in North Atlantic Diadromous Fishes. Bioscience 59:955-965 . doi: 10.1525/bio.2009.59.11.7

List JA, Sinha P, Taylor MH (2006) Using choice experiments to value non-market goods and services: evidence from field experiments. Adv Econ Anal Policy 5:

MacGregor R, Casselman JM, Allen WA, et al (2009) Natural heritage, anthropogenic impacts, and biopolitical issues related to the status and sustainable management of American eel: a 
retrospective analysis and management perspective at the population level. In: Challenges for diadromous fishes in a dynamic global environment. American Fisheries Society, Symposium. pp 713-740

MacGregor R, Mathers A, Thompson P, et al (2008) Declines of American eel in North America: complexities associated with bi-national management. Int Gov Fish Ecosyst Am Fish Soc $357-381$

Maes J, Paracchini ML, Zulian G, et al (2012) Synergies and trade-offs between ecosystem service supply, biodiversity, and habitat conservation status in Europe. Biol Conserv 155:1-12

Magilligan FJ, Sneddon CS, Fox CA (2017) The Social, Historical, and Institutional Contingencies of Dam Removal. Environ Manage 59:982-994 . doi: 10.1007/s00267-017-0835-2

Mateo M, Lambert P, Tétard S, Drouineau H (2017) Impacts that cause the highest direct mortality of individuals do not necessarily have the greatest influence on temperate eel escapement. Fish Res 193:51-59 . doi: 10.1016/j.fishres.2017.03.024

Matthews W, Robison H (1998) Influence of drainage connectivity, drainage area and regional species richness on fishes of the interior highlands in Arkansas. Am Midl Nat 139:1-19

McCleave J (2001) Simulation of the impact of dams and fishing weirs on reproductive potential of silver-phase American eels in the Kennebec River basin. Maine North Am J Fish Manage 21592-605

McClenachan L, Lovell S, Keaveney C (2015) Social benefits of restoring historical ecosystems and fisheries: alewives in Maine. Ecol Soc 20:31

McDowall RM (1997) The evolution of diadromy in fishes (revisited) and its place in phylogenetic analysis. Rev Fish Biol Fish 7:443-462 . doi: 10.1023/A:1018404331601 
McDowall RM (1999) Different kinds of diadromy: Different kinds of conservation problems. ICES J Mar Sci J Cons 56:410-413 . doi: 10.1006/jmsc.1999.0450

McDowall RM (2008) Diadromy, history and ecology: a question of scale. Hydrobiologia 602:5-14 . doi: 10.1007/s10750-008-9290-7

McDowall RM (1988) Diadromy in Fishes: Migrations Between Freshwater and Marine Environments. Timber Press, Portland, Oregon

McLaughlin RL, Smyth ERB, Castro-Santos T, et al (2013) Unintended consequences and tradeoffs of fish passage. Fish Fish 14:580-604 . doi: 10.1111/faf.12003

Meublat G, Lourd PL (2001) Les agences de bassin: un modèle français de décentralisation pour les pays émergents? La rénovation des institutions de l'eau en Indonésie, au Brésil et au Mexique. Rev Tiers Monde 42:375-401

Millennium Ecosystem Assessment (2005) Ecosystems and human well-being. Island Press Washington, DC

Morandi B, Piégay H, Lamouroux N, Vaudor L (2014) How is success or failure in river restoration projects evaluated? Feedback from French restoration projects. J Environ Manage 137:178188 . doi: $10.1016 /$ j.jenvman.2014.02.010

Muir W, Marsh D, Sandford B, et al (2006) Post-hydropower system delayed mortality of transported snake river stream-type Chinook salmon: Unraveling the mystery. Trans Am Fish Soc 135:1523-1534

Myers GS (1949) Usage of Anadromous, Catadromous and Allied Terms for Migratory Fishes. Copeia 1949:89-97 . doi: 10.2307/1438482

Nilsson C, Berggren K (2000) Alterations of Riparian Ecosystems Caused by River Regulation 
Dam operations have caused global-scale ecological changes in riparian ecosystems. How to protect river environments and human needs of rivers remains one of the most important questions of our time. BioScience 50:783-792 . doi: 10.1641/00063568(2000)050[0783:AORECB]2.0.CO;2

Nislow KH, Hudy M, Letcher BH, Smith EP (2011) Variation in local abundance and species richness of stream fishes in relation to dispersal barriers: implications for management and conservation. Freshw Biol no-no

Noonan MJ, Grant JWA, Jackson CD (2012) A quantitative assessment of fish passage efficiency. Fish Fish 13:450-464

Nunn AD, Cowx IG (2012) Restoring River Connectivity: Prioritizing Passage Improvements for Diadromous Fishes and Lampreys. Ambio 41:402-409

OECD (1993) OECD Core Set of Indicators for Environmental Performance Reviews: A synthesis report by the Group on the State of the Environment.

O’Hanley J, Tomberlin D (2005) Optimizing the removal of small fish passage barriers. Environ Model Assess 10:85-98

Olden JD, Konrad CP, Melis TS, et al (2014) Are large-scale flow experiments informing the science and management of freshwater ecosystems? Front Ecol Environ 12:176-185

Pahl-Wostl C, Arthington A, Bogardi J, et al (2013) Environmental flows and water governance: managing sustainable water uses. Curr Opin Environ Sustain 5:341-351

Pahl-Wostl C, Craps M, Dewulf A, et al (2007) Social learning and water resources management. Ecol Soc 1222007

Palmer MA (2008) Reforming Watershed Restoration: Science in Need of Application and 
Author-produced version of the article published in Environmental Management, 2018, 61(4), $671-686$

Applications in Need of Science. Estuaries Coasts 32:1-17 . doi: 10.1007/s12237-008-9129-

5

Palmer MA, Bernhardt ES (2006) Hydroecology and river restoration: Ripe for research and synthesis. Water Resour Res 42:W03S07 . doi: 10.1029/2005WR004354

Palmer MA, Hondula KL, Koch BJ (2014) Ecological restoration of streams and rivers: shifting strategies and shifting goals. Annu Rev Ecol Evol Syst 45:247-269

Palmer MA, Menninger HL, Bernhardt E (2010) River restoration, habitat heterogeneity and biodiversity: a failure of theory or practice? Freshw Biol 55:205-222

Pedersen MI, Jepsen N, Aarestrup K, et al (2012) Loss of European silver eel passing a hydropower station. J Appl Ichthyol 28:189-193

Perkin J, Gido K (2012) Fragmentation alters stream fish community structure in dendritic ecological networks. Ecol Appl 22:2176-2187

Perring MP, Standish RJ, Price JN, et al (2015) Advances in restoration ecology: rising to the challenges of the coming decades. Ecosphere 6:art131 . doi: 10.1890/ES15-00121.1

Podgorniak T, Milan M, Pujolar JM, et al (2015) Differences in brain gene transcription profiles advocate for an important role of cognitive function in upstream migration and water obstacles crossing in European eel. BMC Genomics 16:378 . doi: 10.1186/s12864-015$1589-\mathrm{y}$

Pont D, Bady P, Logez M, Veslot J (2009) EFI+ Project. Improvement and spatial extension of the European Fish Index Deliverable 4.1: Report on the modelling of reference conditions and on the sensitivity of candidate metrics to anthropogenic pressures. Deliverable 4.2: Report on the final development and validation of the new European Fish Index and method, including a complete technical description of the new method. 6th Framework Programme 
Author-produced version of the article published in Environmental Management, 2018, 61(4), $671-686$ The original publication is available at https://link.springer.com/

doi : 10.1007/s00267-017-0992-3

Priority FP6-2005-SSP-5-A. N 0044096. Final Report, 179pp

Porcher JP, Travade F (1992) Les dispositifs de franchissement : bases biologiques, limites et rappels réglementaires. Bull Fr Pêche Piscic 326-327:5-14

Postel S, Richter B (2003) Rivers for life: managing water for people and nature. Island Press

Poulet N (2007) Impact of weirs on fish communities in a Piedmont stream. River Res Appl 23:1038-1047

Quignard JP, Douchement CI (1991) Alosa alosa. In: The Freshwater Fishes of Europe. Aula, Wiesbaden, pp 89-224

Rahel FJ (2013) Intentional Fragmentation as a Management Strategy in Aquatic Systems. BioScience 63:362-372 . doi: 10.1525/bio.2013.63.5.9

Rechisky E, Welch D, Porter A, et al (2009) Experimental measurement of hydrosystem-induced delayed mortality in juvenile Snake River spring Chinook salmon (Oncorhynchus tshawytscha) using a large-scale acoustic array. Can J Fish Aquat Sci 66:1019-1024

Richard S, Bouleau G, Barone S (2010) Water governance in France: institutional framework, stakeholders, arrangements and process. In: Water governance and public policies in Latin America and Europe. Jacobi P. and Sinisgali P. (Eds.). Anna Blume, pp 137-178

Ringuet S, Muto F, Raymakers C (2002) Eels: their harvest and trade in Europe and Asia. TRAFFIC Bull-Camb-TRAFFIC Int- 19:80-106

Rougier T, Lassalle G, Drouineau H, et al (2015) The Combined Use of Correlative and Mechanistic Species Distribution Models Benefits Low Conservation Status Species. PLoS ONE 10:e0139194 . doi: 10.1371/journal.pone.0139194

Sanderson FJ, Donald PF, Pain DJ, et al (2006) Long-term population declines in Afro-Palearctic 
Author-produced version of the article published in Environmental Management, 2018, 61(4), 671-686

migrant birds. Biol Conserv 131:93-105 . doi: 10.1016/j.biocon.2006.02.008

Scholle J, Schuchardt B (2012) A fish-based index of biotic integrity-FAT-TW an assessment tool for transitional waters of the northern German tidal estuaries. EUCC c/o Leibniz-Inst. für Ostseeforschung Warnemünde

Segurado P, Branco P, Avelar AP, Ferreira MT (2014) Historical changes in the functional connectivity of rivers based on spatial network analysis and the past occurrences of diadromous species in Portugal. Aquat Sci 77:427-440 . doi: 10.1007/s00027-014-0371-6

Segurado P, Branco P, Ferreira M (2013) Prioritizing restoration of structural connectivity in rivers: a graph based approach. Landsc Ecol 1-8

Suding KN (2011) Toward an era of restoration in ecology: successes, failures, and opportunities ahead. Annu Rev Ecol Evol Syst 42:465

Susquehanna River Anadromous Fish Restoration Cooperative (2010) Migratory fish management and restoration plan for the Susquehanna River basin

Sutherland W, Freckleton R, Godfray H, et al (2013) Identification of 100 fundamental ecological questions. J Ecol 101:58-67

Svendsen JC, Aarestrup K, Malte H, et al (2011) Linking individual behaviour and migration success in Salmo salar smolts approaching a water withdrawal site: implications for management. Aquat Living Resour 24:201-209

Thuiller W, Albert C, Araújo MB, et al (2008) Predicting global change impacts on plant species’ distributions: future challenges. Perspect Plant Ecol Evol Syst 9:137-152

Tischendorf L, Fahrig L (2000a) On the usage and measurement of landscape connectivity. Oikos 90:7-19 
Tischendorf L, Fahrig L (2000b) How should we measure landscape connectivity? Landsc Ecol $15: 633-641$

Travade F, Dartiguelongue J, Larinier M (1987) Passage of Fish Downstream and through Turbines and Hydroelectric Plants: EDF Experience. Houille Blanche 42:125-133

Tullos DD, Collins MJ, Bellmore JR, et al (2016) Synthesis of Common Management Concerns Associated with Dam Removal. JAWRA J Am Water Resour Assoc 52:1179-1206 . doi: $10.1111 / 1752-1688.12450$

Turner RK, van den Bergh JCJM, Söderqvist T, et al (2000) Ecological-economic analysis of wetlands: scientific integration for management and policy. Ecol Econ 35:7-23 . doi: 10.1016/S0921-8009(00)00164-6

Vannote RL, Minshall GW, Cummins KW, et al (1980) The river continuum concept. Can J Fish Aquat Sci 37:130-137

Verspoor E, Stradmeyer L, Nielsen J (2007) The atlantic salmon: Genetics, conservation and management. Blackwell Publishing Ltd., Oxford, UK

Vinck D (1999) Les objets intermédiaires dans les réseaux de coopération scientifique. Contribution à la prise en compte des objets dans les dynamiques sociales. Rev Fr Sociol 40:385-414 . doi: $10.2307 / 3322770$

Vinck D (2003) L'instrumentation du travail interdisciplinaire: cadrage des échanges et médiation par les objets intermédiaires. Esprit Crit Rev Int Sociol Sci Soc 5:http-www

Vinck D, Jeantet A (1995) Mediating and commissioning objects in the sociotechnical process of product design: a conceptual approach. Directorate General Science, R\&D

Ward J, Stanford J (1995) Ecological connectivity in alluvial river ecosystems and its disruption by 
flow regulation. Regul Rivers Res Manag 11:105-119

Ward J, Tockner K, Schiemer F (1999) Biodiversity of floodplain river ecosystems: Ecotones and connectivity. River Res Appl 15:125-139

Webb J, Padgham M (2013) How does network structure and complexity in river systems affect population abundance and persistence? Limnologica

Welch D, Rechisky E, Melnychuk M, et al (2008) Survival of migrating salmon smolts in large rivers with and without dams. PLoS Biol 6:2101-2108

Wilcove DS, Wikelski M (2008) Going, Going, Gone: Is Animal Migration Disappearing. PLoS Biol 6:e188 . doi: 10.1371/journal.pbio.0060188

Wolanski E, McLusky D, van den Belt M, Costanza R (2011) Ecological Economics of Estuaries and Coasts. Academic Press, London, UK

Wortley L, Hero J-M, Howes M (2013) Evaluating ecological restoration success: a review of the literature. Restor Ecol 21:537-543

Zheng PQ, Hobbs BF, Koonce JF (2009) Optimizing multiple dam removals under multiple objectives: Linking tributary habitat and the Lake Erie ecosystem. Water Resour Res 45:W12417 . doi: 10.1029/2008WR007589

Zylberblat M, Amoros C, Stroffek S (1996) La logique de réhabilitation physique appliquée à un grand fleuve : le Rhône / A Methodology for Physical Restoration applied to a Major River : the Rhône . Rev Géographie Lyon 71:287-296 . doi: 10.3406/geoca.1996.4348 